\title{
HUBUNGAN ANTARA FERTILITAS, MORTALITAS, DAN MIGRASI DENGAN LAJU PERTUMBUHAN PENDUDUK
}

\author{
Hidayatul Ainy \\ Siti Nurrochmah \\ Septa Katmawanti \\ Fakultas Ilmu Keolahragaan Universitas Negeri Malang \\ Email: ainy.hidayatul@gmail.com
}

\begin{abstract}
The low rate of population growth in Klojen Districts, cause the population in the region continues to decrease. Reduced population will affect the availability of human resources in the Klojen District. Therefore, conducted a study entitled "The relationship between Fertility, Mortality and Migration with Population Growth Rate". The purpose of this study was to determine the effect of fertility, mortality and migration to the rate of population growth. This type of research is an explanatory survey. Subjects in this study amounted to 11 urban villages. Data collection using documentation data. Data analysis technique used is a Rank Order technique from Spearman. The results of this study indicate that: (1) The value $\rho$ arithmetic of fertility $0.67>$ value $\rho$ table 0.591 . (2) The value $\rho$ arithmetic of mortality $0.44<$ value $\rho$ table 0.591 . (3) The value $\rho$ arithmetic of in-migration $0.12<$ value $\rho$ table 0.591 . (4) The value $\rho$ arithmetic of out-migration $-0.08<$ value $\rho$ table 0.591 . The conclusion of this study: (1) there is a significant relationship between fertility with population growth rate. (2) there is no significant relationship between mortality, inmigration, and out-migration with population growth rate.
\end{abstract}

Keywords: Fertility, Mortality, Migration, Population Growth Rate

\begin{abstract}
Abstrak: Rendahnya laju pertumbuhan penduduk di Kecamatan Klojen mengakibatkan jumlah penduduk di wilayah tersebut terus berkurang. Berkurangnya jumlah penduduk akan berdampak pada ketersediaan sumber daya manusia yang ada di wilayah Kecamatan Klojen. Oleh sebab itu, dilakukan penelitian dengan judul " Hubungan Fertilitas, Mortalitas dan Migrasi dengan Laju Pertumbuhan Penduduk". Tujuan dari penelitian ini adalah mengetahui pengaruh fertilitas, mortalitas dan migrasi terhadap laju pertumbuhan penduduk. Penelitian ini termasuk jenis penelitian survey bentuk explanatory. Subjek dalam penelitian ini sebanyak 11 kelurahan. Pengumpulan data menggunakan data dokumentasi. Teknik analisis data yang digunakan berupa teknik Rank Order dari Spearman. Hasil penelitian menunjukkan bahwa: (1) Nilai $\rho$ hitung fertilitas $0,67>$ nilai $\rho$ tabel 0,591 . (2) Nilai $\rho$ hitung mortalitas $0,44<$ nilai $\rho$ tabel 0,591 . (3) Nilai $\rho$ hitung migrasi masuk $0,12<$ nilai $\rho$ tabel 0,591. (4) Nilai $\rho$ hitung migrasi keluar $-0,08<$ nilai $\rho$ tabel 0,591. Kesimpulan dari penelitian ini: (1) ada hubungan yang signifikan antara fertilitas dengan laju pertumbuhan penduduk. (2) tidak ada hubungan yang signifikan antara mortalitas, migrasi masuk dan migrasi keluar dengan lajunpertumbuhan penduduk.
\end{abstract}

Kata Kunci: Fertilitas, Mortalitas, Migrasi, Laju Pertumbuhan Penduduk 
Penduduk merupakan subjek dan objek pembangunan. Kondisi penduduk berpengaruh terhadap dinamika pembangunan. Pembangunan dikatakan berhasil apabila kesejahteraan penduduk meningkat. Pertumbuhan penduduk yang pesat tanpa disertai kualitas yang baik akan menjadi beban bagi pembangunan nasional. Teori Malthusian, 1948 (dalam Mantra,2013) menjelaskan bahwa pertumbuhan penduduk dapat dibatasi dengan dua cara yaitu preventive checks dan positive checks. Preventive checks adalah pengurangan penduduk melalui penekanan kelahiran. Sedangkan positive checks adalah pengurangan penduduk melalui proses kematian. Dengan demikian laju pertumbuhan penduduk dipengaruhi oleh kelahiran dan kematian.

Kelahiran memiliki pengaruh positif terhadap laju pertumbuhan penduduk. Meningkatnya jumlah kelahiran akan mengakibatkan laju partumbuhan penduduk menjadi semakin tinggi. Sedangkan kematian berpengaruh negatif terhadap pertumbuhan penduduk. Semakin meningkat jumlah kematian maka laju partumbuhan penduduk akan semakin rendah.

Menurut pendapat Faqih (2010), pertumbuhan penduduk merupakan keseimbangan antara faktor-faktor demografi yang mempengaruhi bertambah dan berkurangnya jumlah penduduk. Secara berkala penduduk bertambah karena adanya kelahiran, dan secara bersamaan penduduk akan berkurang akibat adanya kematian penduduk. Masuknya penduduk ke suatu daerah tujuan dan perpindahan penduduk keluar dari daerah asal juga menyebabkan bertambah atau berkurangnya penduduk di suatu daerah.

Migrasi juga menjadi salah satu faktor yang berpegaruh terhadap laju pertumbuhan penduduk. Ada dua macam migrasi yaitu migrasi masuk dan migrasi keluar. Migrasi masuk mengakibatkan peningkatan laju pertumbuhan penduduk sedangkan migrasi keluar mengakibatkan penurunan laju pertumbuhan penduduk.

Tingginya pertumbuhan pen-duduk memang menjadi salah satu prioritas masalah yang harus segera ditangani terutama di Indonesia. Namun disisi lain, jika angka pertumbahan penduduk terlalu rendah juga akan berdampak buruk terhadap perkembangan daerah. Sehingga masalah tersebut juga perlu untuk diperhatikan. Rendahnya pertumbuhan penduduk sangat mungkin terjadi pada suatu daerah apabila jumlah kelahirannya sangat rendah sedangkan jumlah kematiannya sangat tinggi serta banyaknya penduduk yang keluar dari daerah tersebut yang disebabkan oleh keadaan tertentu.

Tinggi rendahnya pertumbuhan penduduk suatu negara dapat dilihat dari angka laju pertumbuhan penduduk. Yang dimaksud laju pertumbuhan penduduk adalah persentase perubahan jumlah penduduk di suatu wilayah dalam setiap tahunya. Berdasarkan Badan Pusat Statistik Nasional (2016), di Indonesia pada tahun 2016 ini angka laju per-tumbuhan penduduk mencapai $1,26 \%$. Pemerintah akan terus berupaya untuk menekan laju pertumbuhan penduduk agar tidak terjadi ledakan penduduk yang akan mempengaruhi kualitas dan kesejahteraan penduduk. Namun tidak dijelaskan hingga mencapai angka berapa laju pertumbuhan penduduk di Indonesia akan terus ditekan.

Di Kota Malang rata-rata angka laju pertumbuhan penduduknya pada periode tahun 2010-2014 adalah 0,75\% setiap tahunya. Pada periode tahun 2014-2015, laju pertumbuhan penduduk di Kota Malang turun menjadi 0,63\%. Dengan jumlah penduduk sebesar 845.973 jiwa, berarti terjadi pertambahan penduduk sebesar 5.325 jiwa sehingga pada akhir tahun 2015 jumlah penduduk di Kota Malang sebesar 851.298 jiwa. Terdapat 5 kecamatan di Kota Malang dengan laju pertumbuhan penduduk yang berbeda-beda. Kecamatan Kedung-kandang dengan laju pertumbuhan penduduk tertinggi yaitu sebesar $1,16 \%$, kemudian Kecamatan Sukun 0,80 \%, Kecamatan Lowokwaru 0,65\%, Kecamatan blimbing 0,50 \%, dan yang terakhir Kecamatan Klojen dengan laju pertumbuhan penduduk terendah yaitu-0,44 \% (Badan Pusat Statistik Kota Malang, 2016).

Uraian data tersebut me-nunjukkan bahwa angka laju per-tumbuhan penduduk di Kota malang tidak melebihi angka laju pertumbuhan penduduk nasional. Sehingga pertumbu-han penduduk di Kota malang tidak terlalu besar. Namun dari data tersebut 
juga menunjukkan bahwa laju pertumbuhan penduduk di Kecamatan Klojen sebesar -0,44 $\%$. Hal ini meng-artikan bahwa di Kecamatan Klojen tidak terjadi pertambahan penduduk setiap tahunya namun justru penduduknya semakin berkurang.

Laju pertumbuhan penduduk di Kecamatan Klojen pada periode tahun 2014-2015 adalah $-0,44 \%$. Dengan jumlah penduduk sebesar 104.590 jiwa, berarti terjadi pengurangan penduduk sebesar 463 jiwa sehingga pada akhir tahun 2015 jumlah penduduk di Kecamatan Klojen sebesar 104.127 jiwa. Terdapat 11 kelurahan di Kecamatan Klojen dengan laju pertumbuhan penduduk yang berbeda-beda. Kelurahan Rampal Celaket dengan laju pertumbu-han penduduk terendah yaitu -0,50 \%, kemudian Kelurahan Kauman dan Kelurahan Kasin -0,48 \%, Kelurahan Sukoharjo, Kelurahan Klojen dan Kelurahan Kidul Dalem -0,45 \%, Kelurahan Samaan -0,44 \%, Kelurahan Bareng dan Kelurahan Gadingkasri $-0,43 \%$, Kelurahan Penanggungan $-0,41 \%$, dan yang terakhir Kelurahan Oro Oro Dowo dengan laju pertumbuhan penduduk -0,40 \% (Badan Pusat Statistik Kota Malang, 2016).

Sedangkan pada tahun 2016 jumlah penduduk di Kecamatan Klojen sebanyak 103.637 jiwa. Hal ini me-nunjukkan bahwa pada tahun 2016 jumlah penduduk berkurang dari tahun sebelumnya sebanyak 490 jiwa. Ber-kurangnya jumlah penduduk di Kecamatan Klojen ini di proyeksikan hingga tahun 2020 akan terus terjadi. Diperkirakan jumlah penduduk pada tahun 2020 tersisa sebanyak 101.410 jiwa (Badan Pusat Statistik Kota Malang, 2016).

Data tersebut menunjukan bahwa di Kecamatan Klojen jumlah penduduk-nya terus berkurang dari jumlah penduduk tahun sebelumnya. Jika hal ini terjadi secara terus menerus, maka jumlah sumber daya manusia diwilayah tersebut akan terus menurun dan akan berdampak buruk pada perkembangan wilayah tersebut.

Berdasarkan uraian permasalah-an tersebut, penulis tertarik untuk melakukan penelitian yang berjudul "Hubungan antara fertilitas, mortalitas dan migrasi dengan laju pertumbuhan penduduk". Penelitian ini bertujuan untuk mencari faktor-faktor yang berhubungan dengan laju pertumbuhan penduduk.

Laju pertumbuhan penduduk adalah angka yang menunjukan kecepatan pertumbuhan penduduk dalam bentuk angka setiap dalam kurun waktu tertentu. Yang dimaksud dengan pertumbuhan penduduk merupakan keseimbangan antara faktor-faktor demografi yang mempengaruhi perubahan jumlah penduduk baik berkurang atau bertambah, yang terjadi disuatu daerah. Pertumbuhan penduduk dipengaruhi oleh faktor fertilitas ( kelahiran), kelahiran (mortalitas) dan perpindahan peduduk baik masuk atau keluar suatu wilayah (migrasi). Jumlah penduduk bertambah karena adanya kelahiran dan migrasi masuk, sedangkan jumlah penduduk berkurang karena adanya kematian dan migrasi keluar (Faqih, 2010).

Fertilitas atau kelahiran hidup (live birth) adalah terlepasnya bayi dari rahim perempuan dengan adanya tanda-tanda kehidupan seperti bernafas, denyut jantung dan berteriak atau menangis. Jika saat lahir tidak muncul tanda-tanda tersebut maka disebut lahir mati (still birth). Tinggi rendahnya tingkat fertilitas penduduk dipengaruhi oleh dua faktor yaitu faktor demografi dan non demografi. Faktor demografi seperti struktur umur, struktur perkawinan, dan usia kawin pertama. Sedangkan faktor non demografi seperti ekonomi penduduk, tingkat pendidikan, urbanisasi dan industrialisasi (Mantra, 2013).

Menurut Budi Utomo,1985 (dalam Mantra, 2013) kematian adalah hilangnya seluruh tanda-tanda kehidupan secara permanen yang terjadi sewaktu-waktu setelah terjadinya kelahiran hidup. Dengan begitu dapat diartikan bahwa adanya proses kematian selalu didahului oleh proses kelahiran hidup. Sehingga tidak ada kematian jika sebelum proses kehidupan.

Migrasi adalah perpindahan penduduk dari satu daerah ke daerah lainya yang bersifat menetap atau sementara. Menurut Viji (2013), ada dua faktor tertinggi yang menyebabkan seseorang bermigrasi, yaitu faktor pengakuan dan faktor permasalahan ketenagakerjaan. Faktor pengakuan yaitu terkait kegilaan untuk pergi ke kota, gengsi 
5 | Jurnal Preventia Vol.. No..

yang tinggi, dan sebagai simbol kebesaran sehingga mendorong keinginan seseorang untuk mencari daerah yang lebih maju. Sedangkan permasalahan ketenaga-kerjaan yaitu terkait permintaan yang terlalu tinggi terhadap tenaga kerja, gaji rendah dan rendahnya peluang dalam lapangan pekerjaan sehingga hal tersebut menyebabkan seseorang berkeinginan untuk meninggalkan daerah tersebut.

\section{METODE}

Penelitian ini menggunakan metode survey, yaitu suatu metode penelitian yang dilakukan tanpa melakukan intervensi terhadap subjek penelitian atau sering disebut penelitian non-eksperimen.

Jenis penelitian ini adalah penelitian eksplanatory, yaitu penelitian yang menunjukkan hubungan antar variabel ( penelitian korelasional). Jenis penelitian ini diarahkan untuk menjelaskan suatu keadaan atau situasi.

Subjek dalam penelitian ini adalah seluruh penduduk yang lahir, mati dan bermigrasi di Kecamatan Klojen Kota Malang tahun 2016. Teknik pengumpulan data yang digunakan adalah teknik dokumentasi. Sedangkan teknik analisis data yang digunakan dalam penelitian ini adalah uji spearman rank order.

\section{HASIL PENELITIAN}

Hasil dari penelitian ini akan diajabarkan pada Tabel 1 yang menunjukkan jumlah kelahiran, jumlah kematian, jumlah migrasi masuk dan jumlah migrasi keluar penduduk serta angka laju pertumbuhan dimasing-masing kelurahan.

Tabel 1 menunjukkan jumlah kelahiran di Kecamatan Klojen mulai Januari hingga Desember tahun 2016 sebanyak 1.103 jiwa. Dari sebelas kelurahan yang memiliki jumlah kelahiran tertinggi adalah Kelurahan Sukoharjo yaitu sebanyak 158 penduduk yang lahir. Kelurahan yang memiliki jumlah kelahiran terendah adalah Kelurahan Klojen yaitu sebanyak 43 penduduk yang lahir.

Jumlah kematian yang terjadi di Kecamatan Klojen selama tahun 2016 sebanyak 709 jiwa. Kelurahan yang memiliki jumlah kematian tertinggi adalah Kelurahan Oro-oro Dowo yaitu sebanyak 103 penduduk yang mati, sedangkan kelurahan yang memiliki jumlah kematian terendah adalah Kelurahan Klojen yaitu sebanyak 25 penduduk yang

Tabel 1. Data Kelahiran, Kematian, Migrasi Masuk, Migrasi Keluar dan Laju Pertumbuhan Penduduk Setiap Kelurahan.

\begin{tabular}{lccccc}
\hline \multicolumn{1}{c}{ Kelurahan } & Kelahiran & Kematian & $\begin{array}{c}\text { Migrasi } \\
\text { Masuk }\end{array}$ & $\begin{array}{c}\text { Migrasi } \\
\text { Keluar }\end{array}$ & $\begin{array}{c}\text { Laju Pertumbuhan } \\
\text { Penduduk }\end{array}$ \\
\hline Klojen & 43 & 25 & 126 & 190 & -0.34 \\
Rampal Celaket & 69 & 64 & 128 & 161 & -0.18 \\
Samaan & 105 & 66 & 222 & 366 & -0.43 \\
Kidul Dalem & 61 & 29 & 182 & 218 & -0.03 \\
Sukoharjo & 158 & 76 & 114 & 139 & 0.21 \\
Kasin & 89 & 63 & 192 & 287 & -0.19 \\
Kauman & 134 & 63 & 217 & 279 & 0.03 \\
Oro-Oro Dowo & 151 & 103 & 246 & 286 & 0.03 \\
Bareng & 110 & 100 & 390 & 377 & 0.07 \\
Penanggungan & 93 & 61 & 204 & 283 & -0.12 \\
Gading Kasri & 90 & 59 & 124 & 210 & -0.17 \\
\hline \multicolumn{1}{c}{ Jumlah } & $\mathbf{1 1 0 3}$ & $\mathbf{7 0 9}$ & $\mathbf{2 1 4 5}$ & $\mathbf{2 7 9 6}$ & $\mathbf{- 0 . 0 9}$ \\
\hline
\end{tabular}

mati.

Jumlah migrasi masuk di 11 kelurahan di Kecamatan Klojen pada tahun 2016 sebanyak 2.145 jiwa. Kelurahan Bareng merupakan kelurahan yang memiliki jumlah migrasi masuk tertinggi dibandingkan 10 kelurahan lainnya yaitu sebanyak 390 
Ainy, dkk., Hubungan Fertilitas, Mortalitas, dan Migrasi dengan Laju Pertumbuhan | 6

penduduk, sedangkan kelurahan yang memiliki jumlah migrasi masuk terendah adalah Kelurahan Sukoharjo yaitu sebanyak 114 penduduk.

Jumlah penduduk yang keluar dari wilayah Kecamatan Klojen selama tahun 2016 berjumlah 2.796 jiwa. Dari sebelas kelurahan di Kecamatan Klojen yang memiliki jumlah migrasi keluar tertinggi adalah Kelurahan Bareng yaitu sebanyak 377 penduduk. Kelurahan Sukoharjo merupakan kelurahan yang memiliki jumlah migrasi keluar paling sedikit yaitu sebanyak 139 .

Selanjutnya pada Tabel 2 akan dijabarkan hasil analisis korelasi menggunakan uji spearman rank order antara fertilitas, mortalitas, migrasi masuk dan migrasi keluar dengan laju pertumbuhan penduduk.

Tabel 2. Hasil Uji Spearman Rank Order

\begin{tabular}{lccc}
\hline Variabel & $\boldsymbol{\rho}$ Hitung & $\boldsymbol{\rho}$ Tabel & Kesimpulan \\
\hline $\begin{array}{l}\text { Fertilitas dengan laju } \\
\text { Pertumbuhan Penduduk }\end{array}$ & 0,67 & 0,591 & $\begin{array}{c}\boldsymbol{\rho} \text { hitung }>\boldsymbol{\rho} \text { tabel } \\
\text { Ada Hubungan } \\
\text { Mortalitas dengan laju }\end{array}$ \\
$\begin{array}{l}\boldsymbol{\rho} \text { hitung }<\boldsymbol{\rho} \text { tabel } \\
\text { Mertumbuhan Penduduk }\end{array}$ & 0,44 & 0,591 & $\begin{array}{c}\text { Tidak Ada Hubungan } \\
\boldsymbol{\rho} \text { hitung }<\boldsymbol{\rho} \text { tabel }\end{array}$ \\
$\begin{array}{l}\text { Pertumbuhan Penduduk } \\
\text { Migrasi Keluar dengan laju } \\
\text { Pertumbuhan Penduduk }\end{array}$ & 0,12 & 0,591 & $\begin{array}{c}\text { Tidak Ada Hubungan } \\
\boldsymbol{\rho} \text { hitung }<\boldsymbol{\rho} \text { tabel }\end{array}$ \\
\hline
\end{tabular}

Tabel 2 menunjukkan bahwa berdasarkan analisis data menggunakan uji spearman rank order secara manual, diperoleh nilai koefisien korelasi spearman rank $(\rho)$ fertilitas dengan laju pertumbuhan penduduk sebesar 0,67. Nilai koefisien korelasi spearman rank $(\rho)$ mortalitas dengan laju pertumbuhan penduduk sebesar 0,44 . Nilai koefisien korelasi spearman rank $(\rho)$ migrasi masuk dengan laju pertumbuhan penduduk sebesar 0,12 . Sedangkan nilai koefisien korelasi spearman rank $(\rho)$ migrasi keluar dengan laju pertumbuhan penduduk sebesar -0,08. Sementara itu, dengan taraf signifikansi 0,05 diperoleh $\rho$ tabel sebesar 0,591. Sehingga dapat disimpulkan bahwa terdapat hubungan yang signifikan antara fertilitas dengan laju pertumbuhan penduduk. Namun tidak terdapat hubungan yang signifikan antara, mortalitas, migrasi masuk, dan migrasi keluar dengan laju pertumbuhan penduduk.

\section{PEMBAHASAN}

\section{Hubungan Mortalitas dengan Laju Pertumbuhan Penduduk}

Hasil penelitian ini menunjukkan

bahwa fertilitas memiliki hubungan yang signifikan dengan laju pertumbuhan pendududuk. Nilai korelasi fertilitas dengan laju pertumbuhan penduduk sebesar 0,67. Artinya fertilitas dengan laju pertumbuhan penduduk memiliki hubungan yang kuat. Sesuai dengan teori transisi demografi (dalam Ryadi, 2016), yang menyatakan bahwa perubahan keadaan pertumbuhan penduduk dipengaruhi oleh kondisi tingkat tingkat kelahiran dan kematian.

Didukung penelitian Syaadah (2014), bahwa faktor utama pertumbuhan penduduk adalah fetilitas. Pencegahan dan pengendalian angka fertilitas dapat menurunkan laju pertumbuhan penduduk. Penelitian Soleha (2016), menyatakan pertumbuhan penduduk meningkat karena tingginya jumlah kelahiran. Upaya untuk menekan pesatnya pertumbuhan penduduk dapat dilakukan dengan mengurangi jumlah keahiran. Jumlah kelahiran dapat di turunkan melalui penundaan usia perkawinan dan pembatasan jumlah anak dalam keluarga.

Penelitian Burhan (2008), menyatakan pengendalian pertumbuhan penduduk dapat dilakukan melalui upaya penurunan fertilitas. Menurunnya tingkat fertilitas 
berdampak pada penurunan angka laju pertumbuhan penduduk. Hasil penelitian Sunaryanto (2012) juga menunjukkan bahwa pembatasan jumlah kelahiran secara berkala mampu menurunkan laju pertumbuhan penduduk.

Hasil dari keempat penelitian diatas dapat dapat diambil kesimpulan bahwa fertilitas berhubungan dengan laju pertumbuhan penduduk. Pembatasan terhadap fertilitas merupakan salah satu upaya penurunan laju pertumbuhan penduduk. Namun, pembatasan yang berlebihan terhadap fertilitas dapat mengakibatkan rendahnya laju pertumbuhan penduduk.

\section{Hubungan Mortalitas dengan Laju Pertumbuhan Penduduk}

Hasil penelitian menunjukkan

bahwa tidak ada hubungan yang signifikan antara mortalitas dengan laju pertumbuhan penduduk di Kecamatan Klojen Kota Malang. Tidak sesuai dengan teori Malthusian, 1948 (dalam Mantra,2013) yang menjelaskan bahwa pertumbuhan penduduk dapat dibatasi cara positive checks, yaitu pengurangan penduduk melalui proses kematian.

Tidak adanya hubungan yang signifikan bukan berarti bahwa fertilitas dengan laju pertumbuhan penduduk tidak memiliki hubungan sama sekali. Koefisien korelasi sebesar 0,44 menunjukkan bahwa mortalitas dengan laju pertumbuhan penduduk memiliki hubungan yang cukup lemah.

Penelitian Arsyad \& Septi (2016) juga menunjukkan selain kelahiran dan migrasi, kematian juga mempengaruhi laju pertumbuhan penduduk. Jumlah kematian yang tinggi mengakibatkan menurunya pertumbuhan penduduk.

\section{Hubungan Migrasi dengan Laju Pertumbuhan Penduduk}

Hasil penelitian menunjukkan tidak ada hubungan yang signifikan antara migrasi masuk dengan laju pertumbuhan. Koefisien korelasinya sangat rendah yaitu sebesar 0,12. Menunjukkan bahwa hubungan migrasi masuk dengan laju pertumbuhan penduduk sangat lemah. Menurut penelitian Taryono, dkk (2009), laju pertumbuhan penduduk pada dasarnya selain disebabkan oleh tingkat kelahiran juga disebabkan adanya migrasi masuk.

Chowdhury (2013), menetapkan adanya hubungan yang signifikan antara migrasi dengan jumlah penduduk. Populasi disuatu daerah terpengaruh secara signifikan oleh migrasi. Imigrasi (migrasi masuk) berpengaruh positif terhadap pertumbuhan penduduk. Adanya imigrasi mengakibatkan jumlah penduduk disuatu daerah bertambah.

Penelitian ini juga menunjukkan bahwa tidak ada hubungan yang signifikan antara migrasi keluar dengan laju pertumbuhan penduduk. Koefisien korelasi migrasi keluar dengan laju pertumbuhan penduduk hanya $-0,08$. Menunjukkan bahwa hubungan migrasi keluar dengan laju pertumbuhan penduduk sangat lemah. Hubungan keduanya merupakan hubungan negatif, yang artinya adanya migrasi keluar ini mengakibatkan jumlah penduduk berkurang.

Penelitian Fan (2005), menunjukkan bahwa korelasi statistik antara migrasi dan pertumbuhan penduduk tidak signifikan di tahun 1980-an namun menjadi signifikan di tahun 1990an. Dengan demikian,

pengaruh migrasi terhadap pertumbuhan penduduk akan terus meningkat.

Suartha (2016), dalam penelitiannya menunjukkan bahwa selain faktor fertilitas dan mortalitas, migrasi juga memberikan kontribusi terhadap laju pertumbuhan penduduk. Migrasi masuk dapat menambah jumlah penduduk sedangkan migrasi keluar dapat mengurangi jumlah penduduk. Nasrullah (2013), juga menyatakan bahwa migrasi secara signifikan mempengaruhi fertilitas seorang wanita untuk memiliki jumlah anak yang lebih banyak. Sedangkan fertilitas juga memiliki pengaruh yang signifikan terhadap. pertumbuhan penduduk. Sehingga secara tidak langsung migrasi juga berpengaruh terhadap pertumbuhan penduduk.

Menurut Karyana (2015), migrasi dapat menambah dan me-ngurangi jumlah penduduk. Apabila migrasi masuk lebih besar daripada migrasi keluar maka jumlah 
Ainy, dkk., Hubungan Fertilitas, Mortalitas, dan Migrasi dengan Laju Pertumbuhan | 8

penduduk akan bertambah, artinya migrasi memberikan pengaruh positif terhadap pertumbuhan penduduk. Sebaliknya jika migrasi masuk lebih sedikit di-bandingkan migrasi keluar maka jumlah penduduk akan berkurang, sehingga migrasi memberikan pengaruh negatif terhadap pertumbuhan penduduk.

Faktor fertilitas dan mortalitas berkontribusi terhadap pertumbuhan penduduk. Namun menurut Nawiyanto (2009), daripada kedua faktor tersebut arus migrasilah yang memiliki peran utama dalam proses pertumbuhan penduduk. Fertilitas dan mortalitas hanya mempengaruhi sedikit saja terhadap pertumbuhan penduduk.

\section{Penutup}

Berdasarkan hasil analisis data dan pembahasan hasil penelitian, maka dapat disimpulkan, (1) Fertilitas memiliki hubungan yang signifikan dengan laju pertumbuhan penduduk di Kecamatan Klojen Kota Malang tahun 2016. (2) Mortalitas tidak memiliki hubungan yang signifikan dengan laju pertumbuhan penduduk di Kecamatan Klojen Kota Malang tahun 2016. (3) Migrasi masuk tidak memiliki hubungan yang signifikan dengan laju pertumbuhan penduduk di Kecamatan Klojen Kota Malang tahun 2016. (4) Migrasi keluar tidak memiliki hubungan yang signifikan dengan laju pertumbuhan penduduk di Kecamatan Klojen Kota Malang tahun 2016.

Hasil dari penelitian ini perlu untuk ditindaklanjuti supaya memberikan manfaat yang lebih besar bagi banyak orang. Untuk itu peneliti memberikan beberapa saran, bagi pemerintah untuk meningkatkan program-program dan pelayan kesehatan sebagai upaya pengendalian kelahiran dan kematian supaya lebih seimbang. Serta meningkatkan daya tarik daerah dan memperluas lapangan kerja setiap daerah sebagai upaya pengendalian migrasi.

Dan bagi peneliti selanjutnya untuk meneliti lebih lanjut terkait faktor-faktor yang berpengaruh terhadap tinggi rendahnya tingkat fertilitas, mortalitas dan migrasi serta dampaknya terhadap masyarakat.

\section{DAFTAR RUJUKAN}

Arsyad, Syahmida Syahbuddin \& Septi, Nurhayati. 2016. Determinan Fertilitas di Indonesia. Jurnal Kependudukan Indonesia, 11(1): 1-14.

Badan Pusat Statistik. 2016. Indikator Kesejahteraan Rakyat 2016. Indonesia: Badan Pusat Statistik.

Badan Pusat Statistik. 2016. Kecamatan Klojen Dalam Angka 2016. Malang: Badan Pusat Statistik.

Badan Pusat Statistik. 2016. Kota Malang Dalam Angka 2016. Malang: Badan Pusat Statistik.

Burhan, Lalu. 2008. Pengaruh Contraceptive Privalency Rate (CPR) Dan Total Fertility Rate (TFR) Terhadap Efektivitas Program Kb Dan Pemberdayaan Ekonomi Keluarga Dan Peningkatan Kesejahteraan Keluarga Di Provinsi Nusa Tenggara Barat. Jurnal Ilmu Ekonomi dan Manajemen, 4(4): 51-100.

Chowdhury, Bandana. 2013. Migration and Population Growth: A Case Study of Assam. Indian Journal Of Applied Research, 3 (6): 125-127.

Fan, C. Cindy. 2005. Interprovincial Migration, Population Redistribution, and Regional Development in China: 1990 and 2000 Census Comparisons. The Professional Geographer, 57(2): 295-311.

Faqih, Achmad. 2010. Kependudukan: Teori,Fakta dan Masalah. Yogyakarta: Dee Publish.

Karyana, Yayat., dkk. 2015. Mobilitas Pendudukdan Bonus Demografi. Bandung: Unpad Press.

Mantra, Ida Bagoes. 2013. Demografi Umum edisi 2 cetakan ke-15. Yogyakarta: Pustaka Pelajar. 
9 | Jurnal Preventia Vol.. No..

Nasrullah. 2013. Pengaruh Migrasi Dan Faktor Sosial Ekonomi Demografi Terhadap Fertilitas Di Dki Jakarta. Widyariset, 16 (1): 101-110.

Nawiyanto. 2009. Pertumbuhan Penduduk Besuki: Kajian Demografi Historis. Jurnal Humaniora, 21 (2): 174-187.

Ryadi, Alexander Lucas Slamet. 2016. Ilmu Kesehatan Masyarakat. Yogyakarta: Penerbit Andi.

Soleha, Siti. 2016. Studi Tentang Dampak Program Keluarga Berencana di Desa Bangun Mulya Kabupaten Penajam Paser Utara. eJournal Ilmu Pemerintahan, 4 (1): 3952.

Suartha, Nyoman. 2016. Faktor-Faktor yang Mempengaruhi Tingginya Laju Pertumbuhan dan Implementasi Kebijakan Penduduk di Provinsi Bali. Jurnal Kependudukan dan Pengembangan Sumber Daya Manusia, 12 (1): 1-7.

Sunaryanto, Heri. 2012. Analisis Fertilitas Penduduk: Provinsi Bengkulu. Jurnal Kependudukan Indonesia, 7 (1): 19-38.

Syaadah, Nilatus. 2014. Analisis Dampak Pertambahan Penduduk Terhadap Penyerapan Angka Kerja. Jurnal Ilmiah Pendidikan Geografi, 2 (1): 61-70.

Taryono, Rita., Yani, lyan., \& Rahmita, B Ningsih. 2009. Studi Tentang Migrasi dan Implikasinya Terhadap Kemiskinan di Kabupaten Pelalawan. Jurnal Ekonomi, 17 (2): $120-131$

Viji, M Healthy Gnana. 2013. Causes

Of Migration Of Labour In Tirunelveli District. International Refereed Research Journal, 4 (1): 124-132. 